\title{
Powers of a kind: the anomalous position of France and the United Kingdom in world politics ${ }^{1}$
}

Until recent decades European approaches to the study of foreign policy were predominantly historical and normative, revolving around debates over such great themes as realpolitik, intervention, appeasement, imperialism, trade and human rights. These debates are still prominent, but since the 1960s they have been complemented by a more dispassionate tradition of work known as Foreign Policy Analysis (FPA), deriving originally from positivist work in the United States on decision-making and causation. Fortunately the two strands of work have gradually come together, especially in Europe and the countries of the Commonwealth, so that most serious writing about foreign policy now seeks to address both the 'is' and the 'ought' side of the issue. ${ }^{2}$

It has, nonetheless, been notable that one of the most substantial and distinctive of non-US approaches to the study of International Relations (IR), the so-called 'English School', has shown relatively little interest in foreign policy - a conundrum given the importance of European states and strategies to the shaping of the international system in which world politics now takes pace. The reasons for this lie in the preoccupation of the School with the historical evolution of the system, towards what it identified as a 'society of states', and with the key legal and political dilemmas arising from co-existence amidst diversity, or what Hedley Bull called 'the anarchical society'. ${ }^{3}$ Thus Martin Wight, from whom the members of the English School took their lead, wrote little about 'foreign policy', and not at all about decision-making or its domestic sources. This is a shame given the foundations Wight had laid down for thinking about the tension between national and

\footnotetext{
1

${ }^{2}$ For an overview of the history of Foreign Policy Analysis see Valerie Hudson, 'The history and evolution of foreign policy analysis', in Steve Smith, Amelia Hadfield and Tim Dunne, eds., Foreign Policy: Theories, Actors, Cases, 2nd edition (Oxford: Oxford University Press, 2012) , pp13-34. Also Valerie Hudson, 'Foreign policy decision-making: a touchstone for International Relations theory in the twenty-first century', in Richard Snyder, H.W. Bruck and Burton Sapin, Foreign Policy DecisionMaking (Revisited) (New York: Palgrave Macmillan, 2002) pp1-20.

${ }^{3}$ On the English School see Brunello Vigezzi, The British Committee on the Theory of International Politics (1954-1985) (Milan: Edizioni Unicopli, 2005); Tim Dunne, Inventing International Society: A History of the English School (Houndmills: Macmillan, 1998); Andrew Linklater and Hidemi Suganami, The English School of International Relations: A Contemporary Reassessment (Cambridge: Cambridge University Press, 2006). Also Hedley Bull, The Anarchical Society: A Study of Order in World Politics (Houndmills: Palgrave Macmillan, 1977; 4th edition with Foreword by Andrew Hurrell, 2012).
} 
international concerns. John Vincent's book Human Rights and Foreign Policy, commissioned by Chatham House, was one of the few English School works to pick up that challenge ${ }^{4}$.

Wight did, however, focus on the role of the 'powers' in international society, seeing Britain and France as key players in its historical evolution ${ }^{5}$. His approach was a careful combination of realist and Grotian attitudes, in that while he recognised that major states had little option but to follow the rhythms of power, at the same time their actions would decide the degree to which a rule-based system would emerge. They thus have a dual responsibility - to themselves and to the wider community of states. Yet difficulties then arise over which states belong in such an elite, and what roles might be left for those excluded. As to the membership of the 'great powers' group Wight tended to fall back on the circular reasoning implied by a focus on the balance of power: those who troubled themselves with its workings and asserted themselves to achieve (or to disrupt) international equilibrium were by definition great powers. They tended also to abrogate to themselves privileged roles in the key institutions which they themselves set up after wars, such as the Concert of Europe, the League of Nations or the UN Security Council ${ }^{6}$. By extension a middle power was 'a power with such military strength, resources and strategic position that in peacetime the great powers bid for its support'7. Otherwise the term 'power' simply refers to any independent state. ${ }^{8}$

\footnotetext{
${ }^{4}$ R.J. Vincent, ed. (1986), Foreign Policy and Human Rights: Issues and Responses (Cambridge: Cambridge University Press in Association with the Royal Institute of International Affairs); also R.J. Vincent, (1986), Human Rights and International Relations (Cambridge: Cambridge University Press in Association with the Royal Institute of International Affairs.

${ }^{5}$ See Martin Wight (edited by Carsten Holbraad and Hedley Bull) Power Politics (Harmondsworth: Penguin Books, in association with the Royal Institute of International Affairs, 1978); Martin Wight (edited by Gabriele Wight and Brian Porter), International Theory: the Three Traditions (Leicester: Leicester University Press, 1991). Chapter 7 of this reconstruction of Wight's famous lectures is entitled 'Theory of diplomacy: foreign policy', but it consists largely of applying the three schools of Machiavellianism, Grotianism and Kantianism to the general problem of survival in international society. It equates foreign policy to statecraft, seeing diplomacy as the 'narrow' business of negotiation, but does not explore what is involved in the term or consider the interplay between domestic politics and external behaviour. In that it is strangely similar to Kenneth Waltz's later development of neorealism, which in its scientific aspirations is the opposite of Wight's approach. ${ }^{6}$ As demonstrated in R.J. Ikenberry (2001), After Victory: Institutions, Strategic Restraint and the Rebuilding of International order after Major Wars(Princeton: Princeton University Press).

${ }^{7}$ Martin Wight (1979), Power Politics, p65. See also Carsten Holbraad, Middle Powers in International Politics (London: St. Martin's Press, 1984).

8 Ibid, p23.
} 
This notion of middle powerness is the starting point for this article, which focuses on the dilemmas of Europe's two leading foreign policy players over how to conduct themselves in a world in which they are in limbo, neither 'great powers' in the nineteenth century sense, nor average states of the middling rank. The Member States of the EU have been attempting for forty-five years to create a collective diplomacy - first as Nine, then by the end of the 1980s as Ten, from 1995 as Fifteen and now as Twenty-Eight, in a group now over four times the size of the original European Economic Community. At the same time the national governments have wished to have their cake and eat it by also maintaining their national foreign policies. The newer members have been particularly keen to use Europe as an amplifier for their previously faint voices in international diplomacy, while France and Britain have used European solidarity as a platform to maintain a significant international profile for themselves, after 1956 coming to terms with the need for safety in numbers under conditions of bipolarity, and then after the end of the Cold War regaining confidence in their capacity to contribute to the shaping of a new world order.

Throughout the post-1945 period, therefore, Britain and France have occupied what I term here an 'anomalous position' both in Europe and globally. They stand out in their own continent for the resources and outlooks they bring to foreign policy, and are often taken by non-Europeans to be speaking for Europe. Yet in principle they are committed to work for a common European foreign policy. On the wider stage they remain permanent members of the United Nations Security Council (UNSC), yet their influence has been limited by superpower dominance during the Cold War and by the complexities of first globalisation and then civilisational conflict since. Reactions against the age of European imperialism mean that their roles in Asia, Latin America and even Africa are now much diminished.

Successive governments in London and Paris have generally not resigned themselves to a reduced role in world politics as the result of historical change, even if there have been times of crisis and loss of confidence. Neither state shows the slightest sign of accepting a diminution of its role as a permanent member of the UNSC or of renouncing nuclear weapons, while both see themselves as continuing to be leading players in the world economy for the foreseeable future. This despite their increasingly secondary roles during the Cold War, and their frustrations with what passed for 'unipolarity' in the 1990s, to say nothing of the growing shadow of the 'rising powers', with their vastly greater populations, resource-bases and 
potential for growth ${ }^{9}$. From outside Europe it seems to many that London and Paris are hanging on grimly to past glories, and delaying the process of decline and fall which Edward Gibbon (and Paul Kennedy in our own time) have encouraged us to see as inexorable ${ }^{10}$.

Are France and the UK therefore cases of key international players whose activism still serves their national interests, or are they states labouring under an illusion of their wider importance, pursuing policies which impose disproportionate costs on their own citizens? How far, indeed, do they share the same historical destiny? Despite shared geopolitical positions and democratic values they have markedly different political cultures.

Resistance to diminished roles is understandable at one level. Britain and France have been central to the European and global balance of power since the days of Louis XIV. They were leading powers for three centuries, and even now their support is sought by other major actors on a range of issues. Until the trauma of 1940 their great power status was taken for granted ${ }^{11}$. Despite its final outcome the war changed that, with both emerging weaker and overshadowed by the new superpowers ${ }^{12}$. In the 20 years which followed the two states also had to face the rapid dismantling of their empires. Britain also struggled simultaneously with economic stagnation and an over-valued currency, while France's own structural problems were temporarily disguised by the élan of the trente glorieuses and the eventual emergence of Fifth Republic.

Britain and France remain objectively in a separate category from other EU countries, given their UN vetoes, their seaborne deterrents and their continued

\footnotetext{
9 In 2030, on projections form the US Department of Agriculture, Britain and France will occupy $7^{\text {th }}$ and $8^{\text {th }}$ places in the list of the world's largest economies, behind (in order) the United States, China, India, Japan, Germany and Brazil. Bloomberg Business, accessed 15 October 2015. http://www.bloomberg.com/news/articles/2015-04-10/the-world-s-20-largest-economies-in-2030 ${ }^{10}$ Edward Gibbon, The Decline and Fall of the Roman Empire (London: J.M. Dent, 1910 - first published in six volumes between 1776-1789): Paul Kennedy, The Rise and Fall of the Great Powers (London: Unwin Hyman, 1987).

${ }^{11}$ Status in international politics is a combination of objective and subjective indicators, but always entails 'collective beliefs' about ranking on 'valued attributes'. See T.V. Paul, Deborah Welch Larson, and William Wohlforth, eds., Status in World Politics (Cambridge: Cambridge University Press, 2014), pp7-13.

${ }^{12}$ As Gaidi Heimann points out it was striking that France in its extremely weakened state was able to regain its great power status in 1945 and become a permanent member of the Security Council. Gaidi Heimann: 'What does it take to be a great power? The story of France joining the Big Five', Review of International Studies 41:1, January 2015, pp185-206.
} 
willingness to project military force outside Europe. Even Germany, bigger and richer than both, and dominating the eurozone, still keeps a lower profile in foreign policy. Yet if changing historical circumstances over the 70 years since the victory celebrations of 1945 have not reduced the sense of entitlement in London or Paris to a privileged position in international politics, they have steadily undermined the capacity to exert international leadership. Britain had to devalue its currency in 1967 (after eighteen years of being in denial about the over-valuation of Sterling) and soon announced its withdrawal from bases 'east of Suez'13. As Saki Dockrill's exhaustive study concludes: 'The East of Suez decision marked the beginning of Britain's transformation into a modern, medium-sized world power'14. Both states kept out of the Vietnam war, despite US arguments about the similarity with the Korean war in which both had participated. The shared humiliation in Egypt in 1956, and the continuing post-colonial dilemmas over Algeria, Aden and Rhodesia had left their mark.

Thus even during the Cold War doubts were beginning to emerge as to whether past stature would confer future significance. The Soviet Union increasingly saw France and the UK as mere extras in the American-run western world. Developing countries still turned to London and Paris for financial and political support, but also increasingly resented their patronising advice and cynical exercise of economic selfinterest. To many in Africa and Asia the mission civilisatrice continued to animate the ex-colonisers, producing cultural and political alienation.

After 1990 the international position of the two states seemed strengthened - by the collapse of communism, by the triumph of their world-view, by the weakness of Russia, and by the seemingly important role which lay ahead for the European Union - whose foreign policy they led. Yet at the same time United States had begun to talk vaguely of a 'new world order' and calls were growing for reform of the UN Security Council. London and Paris were ready to accept that Germany and Japan had reached the parity of status which merited permanent membership, but were opposed by Italy which orchestrated demands for more far-reaching changes. Countries like Brazil, China, India, Indonesia and Nigeria had reasonable hopes that they, with the potential to outstrip the Europeans economically and politically, would rise to at least equal prominence. Eventually the emergence of the BRICS

\footnotetext{
${ }^{13}$ Susan Strange, Sterling and British Policy: A Political Study of an International Currency in Decline (Oxford: Oxford University Press and the Royal Institute for International Affairs, 1971); ${ }^{14}$ Saki Dockrill, Britain's Retreat from East of Suez: the Choice between Europe and the World? 1945-1968 (Houndmills: Palgrave Macmillan, 2002), p226.
} 
group and of the G20 was to validate their expectations, although the UNSC remains stubbornly unreformed. ${ }^{15}$

In any case, the anomalous position of the UK and France is not synonymous with their UNSC role. Just as important is their pretension to lead European diplomacy, despite Britain placing itself at the margins of the EU and France being increasingly over-shadowed by Germany. Yet the argument that they still have the unique capacity among Member States to project military force outside the region has to be placed in the context of both economic problems and their reduced global reputations. In Beijing, New Delhi, or Moscow, the individual EU states do not have the profile they enjoyed even thirty years ago. When President Xi Jinping of China paid a state visit to Britain in October 2015 his Ambassador in London pointedly remarked publicly that the UK was 'not just a middle range power'16. But the content of the visit, with Britain evidently eager to obtain trade and investment deals while sidelining political difficulties, made the asymmetry of the relationship painfully clear ${ }^{17}$. The era of the Falklands War and of French nuclear tests in the Pacific is now an historical curiosity.

The two countries have not been wholly blind to change or to the need to adjust their horizons ${ }^{18}$. A degree of realism dawned among policy-makers not just through the enforced end of their empires but also through the facts on the ground of the superpowers' spheres of influence. There were regular bouts of angst over a 'descent from power'19. Conversely, it was possible for confidence to revive psychologically, and to some extent economically, through assertive leadership - in Britain during

\footnotetext{
${ }^{15}$ Despite the best efforts of Secretary-General Annan and his High-Level Panel in 2003-4. See David Hannay, New World Disorder: the UN after the Cold War - an Insider's View (London: I.B. Tauris, 2008) pp197-290. Also David Hannay, Britain's Quest for a Role: A Diplomatic Memoir from Europe to the UN (London: I.B. Tauris, 2013) pp249-262.

${ }^{16}$ In a live interview on Channel 4 News, 14 October 2015.

${ }^{17}$ As noted by the main Hong Kong based newspaper: 'Now, Britain has simply recognised the limits of its power and is dealing with China mainly on business, just like virtually every other Western country except the US'. South China Morning Post 21 October 2015: 'Xi Jinping's UK visit shows the changing face of Sino-British relations':

${ }_{18}$ But they have had significant difficulties in adjusting to the cross-pressures - external, domestic, psychological. See David M. McCourt, Britain and World Power since 1945: Constructing a Role in International Politics, (Ann Arbor: University of Michigan Press, 2014).

${ }^{19}$ F.S. Northedge, Descent from Power: British Foreign Policy 1954-1973 (Hemel Hempstead: Allen and Unwin, 1974). Northedge saw this uncertainty as having started after World War I, as the title of his previous book indicated: The Troubled Giant: Britain among the Powers, 1916-1929 (London: Bell, 1966). Thanks to Peter Wilson for reminding me of this.
} 
the Thatcher and Blair eras, and in France through Jacques Chirac's willingness to modernise the country's image, and then to stand up to the United States over Iraq. ${ }^{20}$

Leaders have also had a changing domestic environment to consider. The public's relationship with foreign policy has become more complicated. The growth of ethnocultural diversity rooted in migration, a more mobile labour market and instant global communications, have led to a weakening of assumptions about a selfevident national interest commanding support from across the political spectrum. Opinion is more engaged and divided over the rights and wrongs of interventions, while the finances and opportunity costs of foreign policy are emerging from under their previous shadows.

In principle, therefore, Britain and France represent anomalies at three levels - in the international system, within the European Union and to a degree in relation to their own resources and domestic environments. But an anomaly does not mean irrelevance. International relations is not based on logic or theory. It is an historically-driven and conservative system in which those who have achieved positions of prominence rarely relinquish them willingly, and where many states are quite content for others to assume the responsibilities of leadership. Thus the two European members of the Security Council remain significant powers, albeit of a distinctive kind. Although it is difficult to imagine that their rank will be the same in 100 years time, or even 50, they are not under overt external pressure to reduce the scope of their foreign policies.

In the rest of this article I address the question of whether this state of affairs is sustainable, and whether indeed the two states are fundamentally comparable. This entails looking at what the UK and France aspire to do, and what they actually can do, in their three main areas of concern: European foreign policy, the United Nations Security Council, and the global state system. The analysis concludes by examining

\footnotetext{
${ }^{20}$ By modernising the country's image I refer to Chirac's (eventual) acceptance of the need for no more nuclear weapon tests in the Pacific, and his willingness to offer apologies for the behaviour of the French state at the times of both Dreyfus and Vichy. On nuclear tests see Frédéric Bozo, La politique étrangère de la France depuis 1945 (Paris: Flammarion, 2012), pp223-235. On Vichy see Andrew Knapp, 'Jacques Chirac - Surviving without Leading?' in David S. bell and John Gaffney, eds, The Presidents of the French Fifth Republic (Houndmills: Palgrave Macmillan, 2013), p175. On Dreyfus see George R. Whyte, The Dreyfus Affair: A Chronological History (Houndmills: Palgrave Macmillan, 2008), pp334=336. Christian Lequesne and Maurice Vaisse also claim that 'La contribution la plus originale de Jacques Chirac à la politique étrangère de la France apparaît dans une ouverture sur le monde qui privilégie...le dialogue des cultures et favorise la diversité culturelle'. Christian Lequesne and Maurice Vaisse, eds., La politique étrangère de Jacques Chirac (Paris: Riveneuve éditions, 2013), p23.
} 
what power or influence London and Paris can mobilise in the contemporary world going forwards, and how far the two countries are on divergent paths. What I do not do, for it is both a logically distinct set of issues and one towhich much attention has been given already, is to investigate the nature of the bilateral Franco-British relationship. ${ }^{21}$

\section{Leading Europe?}

The first theme is the EU's attempt to forge a common foreign policy, and the role of the large Member States in that process. The intermittent institutional changes, as with the arrival of the office of 'High Representative' and then the External Action Service, naturally raises external expectations of the EU as a collective actor although these can be just as easily dashed by episodes like the Greek financial crisis $^{22}$. Either way there is a tendency to neglect the role of the key nation-states. This is a mistake, even from the point of view of understanding the Coomon Foreign and Security Policy (CFSP). Britain and France, for example, play a carefully ambivalent role. Both wish to use the Union as a platform for their national diplomacy. At the same time each intends to retain its freedom of manoeuvre, even when that inflicts obvious damage on the image of solidarity. In France the Gaullist tradition seeing Europe as an alternative power centre to the United States is now weaker, but in any case Paris has never had any real intention of bringing foreign policy inside the EU's supranational tent. The British discourse, for its part, continues to stress loyalty to NATO before that to the EU. But NATO is not a foreign policy organisation, and Britain has been glad of support from other Member States on occasions from the Falklands War through Kosovo to the terrorist attacks in London of 2005. Even prime minister Cameron, seemingly so eurosceptic, recognises that going it alone in foreign policy is not a viable option. He talks regularly of the need to work with 'our European partners'23.

\footnotetext{
${ }^{21}$ P.M.H. Bell, France and Britain, 1940-1994: the Long Separation (London: Longman, 1997); Robert Tombs and Isabelle Tombs, That sweet enemy: Britain and France: the history of a love-hate relationship (London: Pimlico 2007); Douglas Johnson, Richard Mayne and Robert Tombs (eds), Cross-Channel currents: 100 years of the Entente Cordiale (London: Routledge, 2004); Alan Sharp and Glyn Stone (eds), Anglo-French relations in the twentieth century: rivalry and cooperation (London: Routledge 2000).

${ }^{22}$ Natalia Chaban and Martin Holland, eds. Communicating Europe in Times of Crisis: External Perceptions of the European Union (Houndmills: Palgrave Macmillan , 2014), pp3-4.

${ }^{23}$ See 'The Prime Minister's speech on Europe, delivered at Chatham House on 10 November 2015. In this robust defence of the need for a referendum on UK membership of the Union, Mr. Cameron accepted that leaving would have significant consequences for national security: 'The EU, like NATO and our membership of the UN Security Council, is a tool that a British Prime Minister uses to get
} 
One of the most obvious anomalies about EU foreign policy relates to the position of Germany, which is still far from operating like a would-be great power. This is a situation which suits London and Paris, even if they occasionally express frustration over German decisions like that to abstain in the UN vote on intervention in Libya in 201124. Conversely the leading role taken by Chancellor Merkl over both Ukraine and the migrant crisis has created a frisson of alarm at the possibility that Germany may be ready to behave like any other powerful state. But it has also not gone unnoticed that Berlin has flip-flopped badly over migration, and that its assertiveness remains limited to the use of economic power and to conflict resolution $^{25}$. If Germany were as active in foreign and defence policy as in economic affairs it would become a quasi-hegemon in Europe. As it is, Germany is content to allow Britain and France to retain the reputation of the region's leading diplomatic players.

London and Paris thus have a strong interest in the status quo in relation to European foreign policy cooperation, where no plan on which they are at odds will make much progress. They work in an informal 'big three' with Germany, on whom they can usually rely for cheque book diplomacy and quiet work behind the scenes. It is effectively a leadership group, even if one which cannot be made too much of, let alone formalised, given the sensitivities of other EU Member States.

The triangle does not always work smoothly, and indeed there are elements of competition and asymmetry about the three bilateral relationships which make it up. The Franco-German relationship has been the motor of institutional change for fifty years, whereas on foreign policy Britain and France have taken most of the initiatives - if not always in tandem. Yet in recent years France has started to work more in harness with Germany than with Britain even on foreign policy, thus moving away from the partnership of the 1990s in the Balkans and in west Africa. This may prove to be a significant trend if the UK continues on its present trajectory.

things done in the world, and protect our country'. https://www.gov.uk/government/speeches/primeministers-speech-on-europe accessed 5 January 2016

${ }^{24}$ Rebecca Adler-Nissen and Vincent Pouliot, 'Power in practice: negotiating the international intervention in Libya', European Journal of International Relations, 20:4, December 2014, pp889-911. The authors stress the technical competence and diplomatic leadership of British and French officials in New York.

${ }^{25}$ Thus Maull' s description ten years ago of Germany as an 'uncertain power', focusing mainly on veto power, still applies. Hanns Maull, 'Conclusion: Uncertain power - German Foreign policy into the twenty-first century', in Hanns W. Maull, ed., Germany's Uncertain Power: Foreign Policy of the Berlin Republic (Houndmills: Palgrave Macmillan, 2006) pp273-286. 
In the event of a BREXIT London will have to find an alternative mechanism for cooperating with the other two big EU states on matters of high politics, as on much else $^{26}$. The latter would not, however, lack an interest in cooperation. France in particular has enough diplomatic interests in common with the UK to wish to keep open good lines of political and intelligence communication ${ }^{27}$.

Both London and Paris know that attempting to stabilise the Neighbourhood, towards the south as well as the east, is a critical priority, and that without the resources of the Union as a whole, and the cooperation of their partners, they - and even the United States - will be relatively powerless to make progress. Germany is critical on eastern issues, but Italy, the Netherlands, Poland, Spain and the post-2004 newer members are also important in building effective common strategies, which require webs of cross-cutting bilateral links on the two fronts, as well as working through the collective EU forum. The growing internal troubles of the Union have tended to obscure how far there has been a convergence among members over the basic interests and objectives of foreign policy, and have obstructed the translation of those objectives into joint actions. But London and Paris cannot afford to be impatient of their less influential partners, or to take them for granted. This would soon lead to a legitimacy deficit in their own policies, in an era where soft power counts and reputational damage abroad rebounds at home.

There is evidence of some recognition of this fact. British and French foreign policy have both become more Europeanised in the sense that they have acknowledged the need for collective actions. In 1998 they seemed willing to extend this into the key field of defence through their joint initiative at St Malo which kick-started what was to become the Common Security and Defence Policy (CSDP). Yet the two nuclear powers have no intention of compromising their 'independent' deterrents by allowing any wider European involvement - not that many other EU states would welcome association with nuclear weapons. The deterrents now exist, paradoxically, as a way of projecting national soft power - that is, as sources of leading power status, and a guarantee of continued permanent membership of the UNSC. Even at

\footnotetext{
${ }^{26}$ As Michael Emerson et. al. point out, Britain's withdrawal from the EU would leave France as 'more clearly in a position to speak for Europe [in the UNSC]'. Michael Emerson et. al., eds, Britain's Future in Europe: Reform, Renegotiation Repatriation or Secession? (Brussels: Centre for European Policy Studies, 2015) p169.

${ }^{27}$ There are plenty of voices, however, which see Britain as becoming less interested in international activism in any case. See Anand Menon, 'Littler England: the United Kingdom's retreat from Global Leadership', Foreign Affairs November/December 2015, and (less weightily) Fareed Zakaria, 'Britain resigns as a world power', The Washington Post, 21 May 2015.
} 
the conventional level the EU has made little progress in developing a truly collective defence presence or identity. Two thirds of the 34 CSDP missions have been civilian operations. The UK and France have not been prominent in many of them. France is only the fifth biggest contributor to civilian missions and Britain the seventh. ${ }^{28}$

On the military side the UK first prioritised Iraq and Afghanistan and then under the Cameron governments actively discouraged the $\mathrm{CSDP}^{29}$. France is keener in principle but in practice it has preferred to act, in Libya (with the UK) and then in Mali, outside the CSDP framework. ${ }^{30}$ The 'battlegroups' of which so many in Brussels had high hopes ten years ago are dead letters - largely because neither London nor Paris, as the two major spenders on armed force, wish to use them ${ }^{31}$. FRONTEX, which might be thought to be a candidate for civil-military cooperation in the management of the EU's external border, is pitifully inadequate ${ }^{32}$. Relatively little integration of European defence industries have taken place, despite the obvious cost incentives. Thus the CSDP has lost momentum. As Karen Smith has said, even France seems to have lost interest in it. ${ }^{33}$ The combination of NATO and the association of defence with national sovereignty means that the EU's defence project has run up against its limits.

There have been some moves towards bilateral Anglo-French defence cooperation, notably in the Lancaster House Treaties of 2010, which envisaged joint nuclear stock piles, and the rationalising of some conventional equipment. But the embarrassing failure to achieve cooperation over an interoperable aircraft carrier over the last

\footnotetext{
${ }^{28}$ According to the Foreign and Commonwealth Office (London: Foreign and Commonwealth Office, Stabilisation Unit: Working in European Union Common Security and Defence Policy Missions. Deployee Guide, October 2014).

29 Jolyon Howorth,Security and Defence Policy in the European Union 2nd edition, (Houndmills: Palgrave Macmillan, 2014) pp118-119.

${ }^{30}$ François Heisbourg, 'A surprising little war: first lessons of Mali', Survival: Global Politics and Strategy, 55:2, 2013 , pp7-18. Claire Mills, The EU's Common Defence and Security Policy: A Fresh Impetus? House of Commons Library Briefing Note, SN06771, December 2013.

${ }^{31}$ For evidence and debate about battlegroups see European Defence Capabilities: lessons from the past, signposts for the future, (London: House of Lords, European Union Committee, 2012), Chapter 3, paras. 63-74.

${ }^{32}$ Evident even before the recent huge increase in numbers. See Anna Triandafyllidou and Thanos Maroukis, Migrant Smuggling: Irregular Migration from Asia and Africa to Europe, (Houndmills: Palgrave Macmillan, 2012), p23.

${ }^{33}$ Karen E. Smith, 'Would BREXIT spell the end of European Defence?', LSE blog July 2015. http://blogs.lse.ac.uk/europpblog/2015/07/02/would-brexit-spell-the-end-of-european-defence/ accessed 24 September 2015.
} 
decade has demonstrated the financial and political obstacles to progress ${ }^{34}$. Indeed progress in most of the areas envisaged has been slow except in counter-terrorism where the incentives are clear and pressing.

A genuine will to share equipment and planning would certainly scale up the two states' international influence. Together the two states dispose of a population of around 130 million, significant nuclear and conventional forces, and a GDP which would put them comfortably in fourth place in the world. Yet the durability of the nation-state makes the chance of real foreign policy integration is close to zero. The proposal made for Anglo-French Union in 1940 now seems an extraordinary pipedream - as indeed it was even in that moment of high emergency ${ }^{35}$. Yet on many issues Britain and France are doomed to work together. Acting alone is always possible but the risks of exposure on any serious initiative are high. This was the conclusion reached as long ago as 1905, leading to the secret military conversations which led both into a war alliance in August 1914 ${ }^{36}$. That was an extraordinary turnaround after the serious clash between the two countries over Fashoda 1898, and illustrated how changes in the external environment frequently bring home the dangers of isolation. Neither state could realistically have acted without the other in the Balkans in the 1990s, while France was quick to ask Britain for help after its intervention in Mali in $2013^{37}$.

The ability to use significant military force theoretically still does mark Britain and France out among their peers. If the two European members of the UNSC will not act, it is unlikely that Europe will be present at all. Crisis-management without a military component is another matter, but here too the presumption has been that London and Paris will lead, as over Kosovo, Libya and Syria. Germany has come more to the fore during the Ukraine crisis, but it still seeks the cover of working with at least one of France and Britain if possible. All three countries were heavily involved in the nuclear negotiations with Iran, where France notably played the

\footnotetext{
${ }^{34}$ A careful recent assessment concludes that 'Given its novelty and non-binding and non-permanent structure, Franco-British cooperation is likely to remain quite weak and unstable for several years'. Alice Pannier, 'Understanding the workings of interstate cooperation in defence: an exploration into Franco-British cooperation after the signing of the Lancaster House Treaty', European Security, 22:4, p555.

${ }^{35}$ P.M.H. Bell, A Certain Eventuality: Britain and the Fall of France (Farnborough: Saxon House, 1974).

${ }^{36}$ Samuel R. Williamson Jr., The Politics of Grand Strategy: Britain and France Prepare for War, 1904-1914 (Cambridge, Mass: Harvard University Press, 1969).

${ }^{37}$ Heisbourg, Survival, p12. France asked Britain for the use of its C17 transport aircraft. Neither state is capable of maintaining the full portfolio of military capabilities needed for its possible engagements.
} 
hard cop, possibly as the result of a diplomatic division of labour, and this $3+3$ framework seems likely to provide the model for major international problems in the future ${ }^{38}$. That is, Britain and France may still count but they increasingly have to work through ad hoc coalitions or contact groups.

The most important structural issue for both national foreign policies is that of European integration, arising from the crisis in the Eurozone. If a an ever-closer union of eurozone members develops Britain will find itself facing a particularly difficult dilemma. Even if it can maintain stable and friendly relations with the group it will be difficult for it to assert foreign policy leadership. The UK has always displayed a split personality in relation to the EU. Now the 'we feeling' which is supposed to characterise European solidarity is barely evident at all in British public discourse. In its place is a self-regarding à la carte approach, harking back to the 'juste retour' thinking of the 1980s. Thus Britain stays out of the euro, and of Schengen, has considered leaving the European Defence Agency (EDA) and has havered over the Common Arrest Warrant. Yet it calls for a common approach to the EU's external borders, demands solidarity over sanctions towards Russia, and wants to roll back the functions of the state (ie of other states) in the Single Market. It also wants its 27 partners to spend more on ODA and on defence, and to cooperate in the fight against Islamist terrorism, to which both Britain and France are disproportionately vulnerable. This uneasy balancing act throws into sharp relief the difficulties of a would-be leading power which is in practice highly dependent on decisions made by its regional partners.

As for France, it has the opposite set of dilemmas. The last twenty-five years have seen the 'embedded bilateralism' of the Franco-German relationship become less balanced as Germany's economic superiority has grown ${ }^{39}$. At the same time the eurozone has moved near to the point where matching political integration might well occur. In this event the separations between the economic and the political, between finance and foreign policy, will become ever more difficult to sustain. Collective decisions taken on resource transfers are bound to affect the external

\footnotetext{
${ }^{38}$ Another explanation for France's tough line is the extent of its economic links with the Sunni Gulf states which are deeply suspicious of Iran. But that factor is also present for Britain. The ' $3+3$ framework' refers to the combination of the EU big three with China, Russia and the US, as the other permanent members of the Security Council. This is also sometimes named the $5+1$, ie the permanent members plus Germany. The terminology used tends to reveal assumptions about the degree of unity among the three Europeans.

${ }^{39}$ Ulrich Krotz and Joachim Schild (2013), Shaping Europe: France, Germany and Embedded Bilateralism from the Elyseé Treaty to Twenty-First Century Politics (Oxford: Oxford University Press), pp244-245.
} 
relations of the individual Member States, and France would have to face up to the issue it has successfully obscured for half a century: does it ultimately wish to remain an independent world power, or does it prefer to forge a European sovereign, with the multiplier of power and resource that implies but also the loss of political identity? Even the halfway house of greater integration short of federalism would limit the French capacity for leadership. Given the fierce attachment to 'a certain idea of France' evident in the reaction to the Paris atrocities of 2015, to say nothing of the rise of the Front National, the deepening of the Eurozone is thus bound to pose the country some agonising dilemmas over power, authority and image.

\section{At the Security Council}

The most obvious shared characteristic of Britain and France in world politics is their membership of the United Nations Security Council (UNSC). Since the end of the Cold War discontent over the status quo has bubbled away. China, frustrated with the failure to reform the IMF, has promoted an Asian Infrastructure Investment Bank, which Britain and France have felt compelled to join. In particular there is pressure for a fair representation in the UNSC of each of the major continents, which makes Brazil and India strong contenders, and Egypt, Nigeria and South Africa rivals for an African seat. The failure to reform the UNSC suits the UK and France from a narrow point of view but leaves them exposed as the two permanent members who have most difficulty in justifying their continued status. Outside the EU many think with some justice that Europe is over-represented, although they are wrong if they conclude that the two Europeans are the only, or even the main, obstacle to change.

Aware of their vulnerability, this is one issue on which London and Paris have stuck closely together. They welcome reform in principle while circumventing any proposals which would cast doubt on the legitimacy of their own membership. They have not found this too hard to do, in part because it is easy to make progressive noises so long as China is likely to use its veto to prevent Japanese accession, and thus any major change. Just as in the 1990s they survived the first determined push for change, so in the new millennium they rode out Kofi Annan's High-Level Panel, 
both of whose two options for change left the existing permanent members and their vetoes untouched ${ }^{40}$.

The current position which the two Europeans share is that the Security Council must be made more representative of a system whose size and structure is far from that of 1945. They support a 'modest expansion' of permanent members to include the 'group of four' (Brazil, Germany, Japan and India) and 'an African member', but not the creation of new veto rights. They also support an unspecified number of new non-permanent members, thus presumably taking the overall size of the SC from 15 to c 25. France has also mentioned the need for a permanent Arab presence of some kind, while in 2013 President Hollande proposed that the P5 (ie the five permanent members) engage in voluntary self-regulation, whereby each would agree not to veto actions aiming to prevent an imminent crime against humanity ${ }^{41}$. The UK Ambassador in New York noted 'with interest the French initiative' welcoming 'the motives that lie behind it as well as the debate which it has sparked'. But his careful words showed that Britain was not fully aligning itself with the suggestion. ${ }^{42}$.

The veto is a powerful symbol of great power status, but up to 2008 France had been responsible for only $6.9 \%$ of all vetoes cast and Britain $12.3 \%{ }^{43}$. Since the end of 1989 the two have not cast a single veto between them. This is because at times they hide behind a US veto, and at others are hamstrung by the positions of the other three permanent members. They have been frustrated, for instance, by the various failures to get agreed Resolutions on aspects of the Palestinian problem, as of the crises over Syria and the Ukraine. But logic must lead to the conclusion, never of course , that the veto has ever less practical meaning for countries in their position, that is of being able to shape events only in conjunction with the more powerful.

No doubt fears of isolation and future crises arising from post-colonial commitments lurk in the political memory as incentives to hold on to the veto. But the main drivers are prestige and, most importantly, conservatism. States do not give up a

\footnotetext{
${ }^{40}$ David Hannay, New World Disorder: The UN after the Cold War - An Insider's View (London: I.B. Tauris, 2008), pp223-270.

38 Laurent Fabius, 'Réformer le droit de veto au Conseil de sécurité', Le Monde, 4 October 2013.

${ }^{42}$ Speech on Security Council Reform by Ambassador Lyall Grant to the UN GA, 12 November 2014, https:/www.gov.uk/government/speeches/security-council-reform-the-uk-supports-new-permanentseats-for-brazil-germany-india-and-japan-alongside-permanent-african-representation Accessed 27 September 2015.

${ }^{43}$ My calculations, from the table in 'France and UN reform', Permanent Mission of France to the United Nations, 6 August 2015, http://www.franceonu.org/France-and-UN-Reform Accessed 27 September 2015.
} 
major perceived advantage of this kind unless compelled or offered considerable compensation in exchange. The two Europeans can fall back on international law, for as permanent members they can veto any change they dislike. But by the same token the association between international law and the status quo powers brings both into disrepute and alienates the excluded, creating tensions for the future.

The EU dimension of this problem used to be raised, both by European integrationists and by impatient third countries: why cannot the two current European seats on the UNSC simply be exchanged for a Single EU seat, which would help move the world towards a continental form of multipolarity? ${ }^{44}$ In practice the other sizeable European states have no interest in this idea. Germany and Italy are keen to exert their own influence in New York, perhaps with an eventual semi-permanent membership in view, while most European diplomats acknowledge that reform and rationalisation would reduce the numerical presence of Europe on the Council.

Yet the majority of EU Member States would clearly prefer to see Britain and France acting on behalf of the Union, rather than ploughing their own furrows. They have argued that the big two should accept some formal obligation to act for and within the acquis politique, as the body of shared foreign policy positions is known. Yet right from the early discussions of this issue at the time of the Maastricht Treaty London and Paris have firmly resisted any notion that their role on the Security Council might be to act as EU representatives, let alone that they should have to work on the basis of a CFSP mandate. Pressure has been exerted, and some ground has been conceded over the last 25 years, but they have held the line. The Treaty on the European Union now states (Article 34)that:

Member States which are also members of the United Nations Security Council will concert and keep the other Member States and the High Representative fully informed. Member States which are members of the United Nations Security Council will, in the execution of their functions, defend the positions and the interests of the Union, without prejudice to their responsibilities under the provisions of the United Nations Charter.

Anyone half-familiar with diplomatic texts will note in this the assertion of Britain and France that their responsibilities to the UNSC have priority. The other Member

${ }^{44}$ For further background see Christopher Hill, 'The European Dimension of the Debate on Membership of the UN Security Council', The International Spectator, XL, No.4, October-December 2005. 
States have to rely on the readiness of the two governments to uphold EU Common Positions and to report back.

In practice, when the EU-28 have been able to agree, London and Paris have shown no interest in breaking ranks. Moreover they try to avoid finding themselves on opposing sides in the Council, although they had apparent differences during the negotiations with Iran, while France was disappointed with the surprise inability of the Cameron government to get parliamentary support for its proposed air attack on Syria after the latter's use of chemical weapons during $2014^{45}$. The real problem, however, is that Britain and France see themselves as being on another level of diplomatic importance power from their EU partners, with their UN status reinforcing the perception in a circular logic. They have no incentive to act as the mouthpieces of a common European foreign policy unless on a line they have set. By the same token they do not have the leverage to convince the 26 to commit more resources to any initiatives they might take - as during the Libyan intervention of 2011. While London and Paris therefore enjoy the freedom of effectively speaking for Europe in the world's major diplomatic forum, they also have to take on the burdens of action.

Like all major states Britain and France blow hot and cold about the United Nations, but as their national positions have weakened they have had to recognise its essential role as a diplomatic forum and as a source of legitimacy - thus France's recent initiative on genocide, and both powers' coming to accept the need for the cover provided by a UNSC Resolution when considering a military intervention. The memory of the failures over Rwanda in 1994 and Iraq in 2003 weigh far more heavily than they would have done during the Cold War. The two European powers increasingly rely on rule-based multilateralism. Accordingly they continue to provide significant support for the UN. They each provide over $5 \%$ of its general financing, amounting together to nearly $11 \%$ of the total, while France is the third largest contributor (7.2\%) and the UK the seventh (6.7\%) to the peacekeeping budget $^{46}$. These figures suggest that however stalled the UNSC might be over the

\footnotetext{
${ }^{45}$ For a criticism of the way parliamentary opinion overturned the usual presumption about the executive prerogative in war-making see James Gray and Mark Lomas, Who takes Britain to War? (Stroud: the History Press, 2014), pp17-30.

${ }^{46}$ The figures for the regular budget are those assessed for 2015. UN Secretariat 29 December 2014. For the peacekeeping budget the percentages are those assessed for the period 2013-15. All are available at www.un.org
} 
world's great conflicts, the two leading Europeans still see the UN (and its specialised agencies) as a vital interest to uphold.

A revived globalism?

Does their commitment to the UN and to the UNSC mean that Britain and France still pretend to a truly global role? An historical perspective would suggest not. As we have seen, after the mass decolonisation of the 1960s Britain soon wound down its military bases east of Suez after 1968, and gave up the Sterling Area. Together with its parallel turn towards the EC this suggested a wish to fall back on the European and transatlantic versions of its 'three circles' ${ }^{47}$. Soon afterwards Diego Garcia was effectively handed over to the United States, leaving Britain with the responsibility but not the power to look after its displaced protect the interests of its displaced inhabitants ${ }^{48}$. Although the Falklands war a decade later was taken by some to indicate the country's return to greatness most informed observers were well aware of the exceptional nature of the campaign.

France did not draw quite such pessimistic conclusions from its loss of empire, partly because of the global spread of its DOM-TOMs - the far-flung départements and territoires d'outre mer which are constitutionally part of the French Republic. But once the defeat at Dien Bien Phu in 1954 had ended its role in Asia, France focused more on Françafrique and on the Middle East, which for Paris are forms of an extended neighbourhood policy. Both France and the United Kingdom have looked to the EC to provide a platform for diplomacy in the Middle East, as with the Venice Declaration of 1980, which remains the touchstone for their policies. It is also no accident that 25 of the 34 CSDP missions have taken place in these two zones (with three more in the Balkans) ${ }^{49}$.

\footnotetext{
${ }^{47}$ Churchill formulated this famous idea in 19486, referring to Britain's unique place at the intersection of the Empire and Commonwealth, the English-speaking world and Europe. These have subsequently often been reinterpreted to refer to the special relationship with the US, the EU and the Commonwealth. See Jamie Gaskarth, British Foreign Policy (Cambridge: Polity Press, 2013), pp66-70. Robin Niblett has recently recast the idea in terms of concentric circles, with the EU at its heart, the US relationship next and a wider set of relationships, bilateral and institutional in the third and outer ring. Robin Niblett, Britain, Europe and the World: Rethinking the UK's Circles of Influence (London: Chatham House, the Royal Institute of International Affairs, 2015).

${ }^{48}$ Peter Harris, 'America's other Guantánamo: British foreign policy and the US base on Diego Garcia', The Political Quarterly, 86: 4, October-December 2015, pp507-514.

${ }^{49}$ CSDP Map Mission Chart, European Institute of Security Studies (Paris) October 2014, www.isiseurope.eu accessed 5 January 2016. The only exceptions are Aceh (Indonesia), Georgia and the Ukraine.
} 
The 1990s saw foreign policy confidence revive on the back of victory in the Cold War, culminating in the ideas of the Responsibility to Protect (R2P) and le droit d'ingérence. Britain's part in the defeat of Saddam Hussein in 1991, and France's anxiety over the performance of its own forces in that conflict, revived the ambition to play a role in the wider international system. Tony Blair was emboldened to participate in five major military campaigns, four of which were out of area. France continued its tradition of intermittent interventions in African states, was a big contributor in Afghanistan, and would have been willing to join the 2003 attack on Iraq had a satisfactory UN Resolution been forthcoming. The two countries have been central to the EU's anti-piracy operation in the Indian Ocean. Their intervention in Libya in 2011 was decisive in the fall of Colonel Gaddafi.

This recent pattern might suggest that Britain and France have overcome their anomalous positions in world politics. Outside the P5 there are no other states which are as active, militarily or diplomatically, and over such a wide range. It can also be argued that a strict distinction between global and regional roles, with the Europeans restricting themselves to the latter, makes less sense than it did in the age of superpower spheres of influence, and when their trade seemed likely to become concentrated within the EU and its associated economic area. Now that the international system is more fluid, the spatial image of geopolitics has become overlaid by the unpredictable transnationalism of diasporas, migration, social movements, capital markets and terrorism. The idea of 'spheres of influence' still has analytical if not normative traction, but regions no longer look so distinctive or selfcontained as even twenty years ago ${ }^{50}$. Certainly the idea of fortress Europe is now only a distant mirage ${ }^{51}$.

The logic here is not that states like Britain and France are re-engineering the global roles they lost during the 1960s. Rather it represents a paradox: on the one hand they cannot expect to shelter behind a regional cordon sanitaire; they have to assume unforeseeable events and linkages with other parts of the world. On the other hand they cannot pretend to systemic responsibilities or to a full spectrum of capabilities. They have to be highly selective in their engagements, diplomatic, political and commercial. With respect to military intervention, caution is the watchword on both

\footnotetext{
${ }^{50}$ Andrew Hurrell, On Global Order: Power, Values, and the Constitution of International Society (Oxford: Oxford University Press, 2007), pp239-261.

${ }^{51}$ In fact this fanciful idea was compromised from the start by the fact that the external border had never been defined, let alone agreed and protected. Jan Zielonka, ed. , Europe Unbound: Enlarging and Reshaping the Boundaries of the European Union (London: Routledge, 2002).
} 
political and financial grounds, while geography acts as a powerful constraint. The lack of heavy-lift transport aircraft and the continued dependence on US satellite intelligence epitomise the inability even of these two rich and powerful states to project force independently much beyond the Sahara or the Balkans.

A traditional approach to power in foreign policy emphasises the theatres in which a state might count for something (or not). In that sense Britain and France have not been major players in the Americas (the Caribbean excepted) for two centuries, while their roles in mainland Asia came to a halt in the mid-1950s. Since then their foreign policies have largely focused on Africa, the Levant, the Persian Gulf, and more recently west Asia in the form of Afghanistan. They may be concerned about Ukraine, the Caucasus, Kashmir, or Hong Kong, but their ability to affect the fate of these places is minimal. Even in France's supposed chasse gardée of central Africa there have been as many demonstrations of impotence as of decisive intervention, just as Britain ran out of options with Idi Amin in Uganda and Robert Mugabe in Zimbabwe. Both rely on local powers to defeat Boko Haram, if indeed that proves possible $^{52}$. In the intractable Israel-Palestine conflict neither has been able to make a difference and they both have no choice but to wait on initiatives from Washington. In the Persian Gulf their engagement seems more reactive and opportunistic than strategic ${ }^{53}$.

Yet important as geopolitics is, it is not the whole story. Horizontal issues such as climate, poverty, health, migration and religious fundamentalism throw up key dilemmas. Since these issues do not respect boundaries their impacts show up in unpredictable ways and places. No state can afford to be indifferent to them, least of all open societies which rely on free trade, economic growth and the free flow of people and ideas. The citizens of Britain and France are active, and thus exposed, globally - while issues which seem remote geographically or historically can blowback to cause trauma at home.

Britain and France have attempted leadership on some of these 'functional' questions, especially those with security implications. They are key players in international cooperation on counter-terrorism. On poverty successive British

\footnotetext{
${ }^{52}$ For an analysis of how difficult it is for European interventions in Africa to achive their objectives, see Elizabeth Schmidt, Foreign Intervention in Africa: from the Cold War to the War on Terror (Cambridge: Cambridge University Press, 2013), especially pp193-230.

${ }^{53}$ As argued in relation to Britain by David B. Roberts, 'British national interest in the Gulf: rediscovering a role'. International Affairs, 90:3, (2014) 663-677.
} 
governments have prioritised the needs of the 'bottom billion', eventually enshrining in law a commitment to keep ODA at or above $0.7 \%$ GNP. France claims the rank of a leader in reducing greenhouse gas emissions over the last 20 years, and is now prioritising initiatives on climate change. It has quadrupled the price of carbon in an attempt to boost renewable energy, and hosted a huge conference in Paris in December 2015 which to the surprise of many produced an innovative UN agreement, signed by $195^{54}$.

On the increasingly dramatic challenge posed by migration movements, and the associated problems of integrating diverse and fast-changing societies in conditions of international tension, neither country has a coherent approach to offer. The problem has geopolitical as well as functional dimensions, which have combined to place all European countries on the defensive. Britain and France are the only two which could in principle address the 'root causes' of the problem in the Maghreb and the Levant, assuming that the EU cannot act as one, but as we have seen the options there are very limited.

A relatively new development in foreign policy is concern with the image held by outsiders - at its crudest, the question of a country's 'brand'55. This is a particularly difficult problem for traditional powers like Britain and France, whose period of glory seems behind them, and for whom the future promises further relative decline. The problem is compounded by their increasing reliance on soft power in the form of cultural diplomacy and reputation, both of which require the cooperation of civil society ${ }^{56}$. Nearly half a century ago Martin Wight wisely observed that:

Powers which have declined from former greatness, like Britain and France, or which have not attained great power, like India, naturally emphasise the value of political maturity and moral leadership, though these phrases are more likely to carry weight within their own frontiers than beyond ${ }^{57}$.

\footnotetext{
${ }^{54}$ See the 'Climat' section of the website of the French Ministère des Affaires Étrangères, France Diplomatie, www.diplomatie.gouv.fr . Also http://www.cop21.gouv.fr/en both accessed 5 January 2013. French leadership did not waver despite the distraction of the terrorist murders only two weeks before, and the accompanying security challenges of hosting 150 world leaders and many thousands of delegates and NGO representatives.

${ }^{55}$ Simon Anholt, Competitive Identity: The New Brand Management for Nations, Cities and Regions (London: Palgrave, 2006).

${ }^{56}$ Christopher Hill and Sarah Beadle (2014), The Art of Attraction: Soft Power and the UK's Role in the World (London: British Academy).

${ }^{57}$ Wight (1979), Power Politics (Harmondsworth: Pelican Books, with the Royal Institute of International Affairs), p26.
} 
The gap between self-esteem and reputation is still evident, while it can now also be observed inside the two states given the presence of minorities which have not been raised on the myths of Europe's civilising mission. Today governments in Paris and London like to think that the balance-sheet of empire might be seen in a more positive light than fifty years ago. But if anything the reverse is the case. Fourteen Caribbean states are attempting to sue Britain, France and the Netherlands, via CARICOM, for the long-term damage done by the transatlantic slave trade ${ }^{58}$. David Cameron was received coolly by the Jamaican parliament when he refused to envisage reparations for slavery, and reminded his audience that Britain had (eventually) taken the lead in abolishing the slave trade ${ }^{59}$. The atrocities committed by British troops in Kenya have been brought to light by historians, leading in June 2013 to the Government expressing regret and agreeing compensation for victims, and more recently to the unveiling of a memorial in Nairobi to its own sins ${ }^{60}$. Similarly, the last two French presidents have felt it necessary to acknowledge the brutality and injustices inflicted on the Algerian people by France, although they have not issued a formal apology. The eating of humble pie may be a mark of civilised behaviour, but it does not denote the insouciance usually displayed by major powers.

In this context it is difficult to promote not just a favourable national image and the exports which go with it (as through the 'Great' campaign which the UK has been running since 2012 on the back of the London Olympics ) but also European values of democracy, liberty and pluralism ${ }^{61}$. China enjoys a distinct political advantage in African countries, for example, through not having been their coloniser, while British and French actions can still be seen as forms of interference in internal affairs even when they have benign intentions. Domestic pressures to make human rights a key plank of foreign policy complicate things further.

This is, to a degree, unfair given the wish of millions of poor migrants to better their lives in Britain and France. But politics is not a fair trade. In both countries some

\footnotetext{
${ }^{58}$ Al Jazeera America, 27 September 2013, http://america.aljazeera.com/articles/2013/9/27/14-caribbeannationssueeuropeancountriesforreparationsoverslaver.html accessed 4 October 2015.

${ }^{59}$ The Guardian, 2/3? October 2015.

60 'Britain unveils memorial to its atrocities in Kenya', The Times, 12 September 2015. On the historical record see David Anderson,

${ }^{61}$ For the 'Great' campaign, see www.gov.uk/britainisgreat This extensive official PR campaign has been driven by the Cabinet Office which requires all ministries to buy into it, and mobilises publicprivate partnerships to celebrate in unembarrassed (indeed somewhat kitsch) fashion the good things about Britain, its products and its services.
} 
young people, usually from the second and third generations of migrant families, have turned against the state, even to the point of launching terror against their fellow citizens. Slow-burning historical and cultural resentments, further fuelled by national foreign policy and its involvement in wars 'in Muslim lands', have produced this degree of alienation ${ }^{62}$. Such discontents are now played out globally through social media, making it impossible for Britain and France to maintain the fiction of national unity over foreign policy. Even the image of stable, civilised, societies, on the basis of which they criticise others and claim positions of international responsibility, can get called into question ${ }^{63}$.

\section{Conclusions}

This discussion began with the assumption that France and the UK occupy a distinctive niche in world politics. What then should we conclude about the likelihood - or indeed the desirability - of this position being maintained? How much of a gap exists between aspiration and practical capacity? How compatible are the international roles of the two states with their domestic circumstances, and with the preferences of their citizens?

This last question requires an acknowledgement that the two countries have markedly different social systems and political cultures. French leaders still enjoy remarkable freedom of manoeuvre given the mix of consensus and indifference which characterises public opinion in this area. Whether cause or effect, the public and the elite seem to move in harness, as with the steadily more important place given to human rights over recent decades, and the continued absence of any debate over the force de frappe. The continuity which French foreign policy has displayed under the Fifth Republic is broadly supported by the French population, with the notable exception of the connections made by some alienated young people in the banlieues to the state's role in the Muslim Middle East. The aspiration to an elevated position among the powers, that is to grandeur, remains unmoved. To that extent De Gaulle's vision of a strong executive going hand in hand with a confident foreign policy has been vindicated. Its long term durability may be doubted, but for the moment society has rallied behind the state and its determination to carry the fight to its enemies. The terrorist attacks have, indeed, made it impossible to open up a normal political debate about foreign policy.

\footnotetext{
${ }^{62}$ See Andrew Hussey (2014), The French Intifada: the Long War between France and its Arabs (Granta) ${ }^{63}$ Christopher Hill (2013), The National Interest in Question: Foreign Policy in Multicultural Societies (Oxford University Press).
} 
In Britain by contrast pressure groups focusing on international affairs have proliferated and the idea of foreign policy as an Establishment preserve has virtually disappeared, despite the lack of the constitutional upheaval experienced in France. ${ }^{64}$ The deep divisions caused by the Iraq War, together with the remarkable growth of International Relations courses in UK higher education, are factors which help to explain this trend. But there are also deeper reasons. Britain has long had a lineage of what A.J.P. Taylor called the 'troublemakers' on foreign policy ${ }^{65}$. Nineteenth century Liberals argued about human rights, and Tories about free trade. The Labour Party has agonised since its inception over defence and over a 'socialist foreign policy' and continues to make these debates a priority. The modern Conservative Party, notorious for knowing how to hold onto power, is nonetheless racked by public divisions over the EU66.

No contemporary British government, therefore, enjoys the freedom from domestic constraints of its equivalent in Paris. The evident public uneasiness in the UK about further military interventions abroad creates uncertainty in decision-makers' minds, while the excitable treatment of international affairs in the British media adds to their nervousness. Since there are as many pressures to 'do something' as there are to avoid adventurism. there is now hardly an issue in external relations which does not have the potential for producing pressure and embarrassment.

In the international dimension proper of the 'anomaly', meaning how Britain and France perform in world politics, the two states display more structural similarities but also subtle differences. In the first circle of activity, the European Union, both countries find themselves in the unique and difficult situation of trying to square a great power tradition with the need to make multilateralism work. The British case is the more obvious of the two. With the public divided on whether membership of

\footnotetext{
${ }^{64}$ For the foreign policy process in Britain see Gaskarth, 2013, pp41-58. Recent writing on French foreign policy-making is scarcer. See Kessler, Marie-Christine, La Politique étrangère de la France. Acteurs et processus (Paris: Presses de Sciences Po, 1999). Also Frédéric Charillon, La politique étrangère à l'épreuve du transnational: Une étude des diplomaties française et britannique dans la guerre du Golfe (Paris: L'Harmattan, 1999). In Britain the increased debate on FP is not unrelated to the country's developing constitutional crisis. See Andrew Dorman, 'The defence and security implications of Scottish independence', International Affairs, 90:3, May 2014, pp679-696.
}

${ }^{65}$ A.J.P. Taylor, The Troublemakers: Dissent over Foreign Policy, 1792-1939 (London: Faber \& Faber, 1957).

${ }^{66}$ On the way these foreign policy issues have been inextricably interlaced with domestic politics (even if these connections are not always recognised) see Andrew Gamble, Between Europe and America: the Future of British Politics (Houndmills: Palgrave Macmillan, 2003). 
the EU is necessary at all no government can go beyond a loose relationship with Brussels, plus opt-outs. Yet Britain also often wants to opt-in when it suits it - as when it needed European solidarity against Russia after the murder in London of Alexander Litvinenko, or with the need for UK border controls to operate in Calais or Brussels rather than Dover and London, or with the government's recent demand for a say on certain decisions within the eurozone ${ }^{67}$. This produces an ambivalent and unstable relationship for both London and its partners. Britain has become more than an 'awkward partner'. Even if the referendum vote goes in favour of remaining in the EU it is at risk of becoming constitutionally isolated. From an analytical point of view it is certainly in an category of its own ${ }^{68}$.

The French case is also distinctive, but for very different reasons. France is committed to the European project, so long as it can exert joint leadership with Germany. For decades that was not in issue, given the broad equality between the two states, and a division of labour whereby Germany led on institutional and economic issues, and France on foreign policy. But as the balance of power has changed between Berlin and Paris, with Germany becoming more assertive in external policy and clearly outweighing France economically, French options have become more limited. This is particularly difficult given the continuing need to square rhetoric about deeper integration with the continued attachment to French sovereignty and a high international profile - a tension which the emergence of euroscepticism, led by the Front National, has brought clearly into the open.

In the second circle, that of the UN Security Council, the two countries face virtually identical issues. Their privileged positions, which derive from their importance in 1945 (or in France's case from before the War), can still be justified given their willingness to make a proportionate commitment, financial and political, to the UN. Although Russia has a population more twice the size of either, plus a huge land area, it is not clearly a more significant international actor than the two Europeans. Putin's leadership aims to restore his country to great, indeed super, power status,

\footnotetext{
${ }^{67}$ On Litvinenko, see 'Europeans lukewarm as Britain tried to rally support in row with Russia', The Guardian 18 July 2007. On the eurozone, see David Cameron's 'Letter to Donald Tusk', 10 November 2015, at https:/www.gov.uk/government/publications/eu-reform-pms-letter-to-president-of-theeuropean-council-donald-tusk Accessed 5 January 2016. In this letter the prime minister, referring to the eurozone, says that 'any issues that affect all Member States must be discussed and decided by all Member States' .

${ }^{68}$ Stephen George (1998), 3rd edition. An Awkward Partner: Britain in the European Community (Oxford: Oxford University Press).
} 
but his very assertiveness is a testimony to weakness. France and the UK have not made the mistake of trying to turn back the clock. They accept that they are fundamentally weaker than the USA and China, even in some respects than Russia. But they believe that they contribute more to the management of international order than either Russia or China, and are not willing to cede ground to newer, less experienced powers. Furthermore they can protect their status through the resistance to change of the other permanent members, and ultimately through their own vetoes.

Maintaining this strategy rigidly will incur increasing diplomatic costs. This is why they support in principle the reform and the expansion of UNSC membership. It is possible to imagine that in 50 years nothing will have changed on this front, but in that case it is extremely unlikely that the UN will still have a central place in world politics. The excluded rising powers will have pressed for alternative fora, just as the G20 supplanted the G8, where Britain and France will not be guaranteed front row seats. Thus the two have a strong interest in jointly parlaying their position as emblems of the old order into a role as a bridge between the past and a reformist future. This is not quite as tough as the dilemma facing the Romanovs in 1905, but it will not be easy. The most likely scenario is an expansion of UNSC membership without any loss of seats for France and the UK. But even in that case their influence will be significantly diluted.

The last aspect of the anomaly relates to the degree of ambition to play a global rather than a restricted regional role. The key symbol here, closely linked to the issue of UNSC membership, is the maintenance of nuclear weapons. Britain and France are two of only nine nuclear powers in a General Assembly of 193 states. The issue of why they want a nuclear deterrent when the vast majority do not feel the need is a matter mostly of political argument. On the basis of pure logic it is difficult to see a serious rationale, unless one supposes both that another nuclear power (eg Russia) might threaten to attack Europe, and that the United States would stand aside. Both hypotheses are wildly implausible, as is the idea that a terrorist group capable of planting a dirty bomb would be deterred by sea-based missiles. The possession of nuclear weapons by the two European countries is thus anomalous even as an insurance policy. And if the deterrent is to be both truly independent and have an invulnerable second strike capability it will eat up resources, with significant opportunity costs for a middle range power. There are clearly fewer doubts in 
France than in Britain about the desirability of meeting these costs, and indeed about the deterrent as a symbol of political independence.

Another explanation (if not justification) for retention applies equally to both states. It is the perceived need to preserve status, especially in the UNSC, linked in turn to domestic politics. Any decision to give up nuclear weapons would provoke a political crisis in each state, and quite possibly international instability as well. That might turn out to have positive aspects, but it could well go the other way. The combination of prospective domestic upheaval and international uncertainties represents a huge barrier for any government which might contemplate breaking the link between its power status and the possession of nuclear arms ${ }^{69}$. Thus in this case the risk represented by change exists more in political than strategic terms, but it is no less inhibiting for that. Path dependency can make the prospect of change like this literally unthinkable.

Britain and France have implicitly recognised for decades their vulnerability to being overtaken by new forces in hard power terms. This is not simply a matter of Brazil, China and India. Countries like Indonesia, Nigeria, South Africa, Mexico have great potential through their size and resources. Their lack of effective infrastructures, and relative introspection will not last forever. Other western states like Canada, Poland, Spain and Australia might also decide that they no longer wish to play second fiddle to European states whose claim to pre-eminence rests increasingly on unusable weapons and the historical record. In effect the two Europeans have done remarkably well to delay the process of relative decline, and may be able to continue on the same path for some while yet.

If so they will need to rely on the soft power which has been a comparative advantage $^{70}$. Yet even here there are limitations. Their political influence, even in regions where they have been historically present such as Africa and the Middle East, is now effectively dependent on working with the United States, and/or the EU, while in economic terms it will be a struggle to sustain current living standards, competitiveness and hi-tech leadership. The stigma of imperialism, as we have seen, is far from fading and is revived by every misjudged military intervention, with

\footnotetext{
${ }^{69}$ William Walker, 'Trident's replacement and the survival of the Unite Kingdom', Survival: Global Politics and Strategy, 57:5, October-November 2015, pp7-28.

${ }^{70}$ For an attempt to measure soft power, which ends by ranking the UK first, see Jonathan McClory, The New Persuaders III: a 2012 Global ranking of Soft Power (London: Institute for Government, 2013).
} 
damaging consequences for the branding policies now being enthusiastically pursued in London and Paris.

Accordingly Britain and France are in dire need of some radical thinking in foreign policy, enabling them to build on their distinctive qualities and range of external relations without being defensive about matters of status. Their anomalous position needs putting to good use, not merely protecting. That would seem to require working with other states, particularly within the European Union - and indeed with each other - but also more variably. Attitudes also need adjusting, to avoid being caught in the stale binary of nationalism versus internationalism, given that foreign policy is now more than ever about balancing constituencies at home and abroad ${ }^{71}$. Our changing populations, assets and challenges require that we remain engaged with the world, without at the same time presuming an eternal right to leadership. It is, however, difficult to learn national humility after centuries of being powers - and powers of a very particular kind.

\footnotetext{
${ }^{71}$ An argument developed in Christopher Hill, Foreign Policy in the Twenty-First Century, second edition, (London: Palgrave, 2016).
} 